\title{
Research Paper Existing status of SHGs in terms of employment and income generation
}

\section{- RADHIKA BHONGALE, D.P. HARDIKAR AND Y.J. WAGHMODE}

See end of the paper for authors' affiliations

Correspondence to : RADHIKA BHONGALE Department of Extension Education, College of Agriculture, Dr. B.S. Konkan Krishi

Vidyapeeth, Dapoli, RATNAGIRI (M.S.) INDIA

Email : radhika5101990@ gmail.com

\section{Paper History :}

Received : 13.01.2017;

Revised : 07.02.2017;

Accepted : 17.02 .2017
Abstract : The present study was conducted in Dapoli and Guhagar tahsils of Ratnagiri district (Konkan region) and Baramati and Indapur tahsils of Pune district (Western region) of Maharashtra. The sample constituted of 120 SHGs heads from 12 villages. Respondents differed significantly with respect to profile characteristics namely, self education, attitude towards SHG scheme, information seeking behaviour, institutional training received and market orientation. The other characteristics namely, age of group, pre-scheme annual income, knowledge about SHG scheme, social participation and extension contact showed non-significant difference between the two regions. In case existing status of SHGs in terms of employment and income generation maximum number ( $35.00 \%$ each) of the respondents had got 'medium' and 'low', that is, 24 to 66 person days and upto 23 person days additional employment,more than about two-third (65.00\%) of the respondents had received 'medium' (Rs. 10,201/- to 36,400/-) additional income, while, 16.67 per cent each had received 'low' (upto Rs. 10,200/-) and 'high' (Rs. 36,401/- and above) category of additional income, respectively.

KEY Words : Existing status, Self-help group, Employment generation, Income generation

How To Cite This PAPer : Bhongale, Radhika, Hardikar, D.P. and Waghmode, Y.J. (2017). Existing status of SHGs in terms of employment and income generation. Internat. Res. J. Agric. Eco. \& Stat., 8 (1) : 153-161, DOI : 10.15740/HAS/IRJAES/8.1/153-161. 